\title{
A QUALITATIVE STUDY ON KNOWLEDGE AND DIETARY INTAKE AMONG MOTHERS WITH STUNTED CHILDREN UNDER FIVE IN JEPARA, CENTRAL JAVA
}

\author{
Ani Margawati, Ari Budi Himawan, Dea A Adespin, \\ Arwinda Nugraheni
}

Department of Public Health, Faculty of Medicine, Universitas Diponegoro

\begin{abstract}
Background: Stunting is the impaired growth and development that children experience from poor nutrition, repeated infection, and inadequate psychosocial stimulation. Children are defined as stunted if their height-for-age is more than two standard deviations below the WHO Child Growth Standards median. Some of the consequences of stunting in early life include poor cognition and educational performance, low adult wages, lost productivity and, when accompanied by excessive weight gain later in childhood, an increased risk of nutrition-related chronic diseases in adult life. This study aimed to describe perception of stunting and analyze the associations of maternal knowledge and dietary intake on the risk of stunted children under five in Jepara, Central Java.

Subjects and Method: This was a qualitative study conducted in Jepara, Central Java. A sample of 44 stunted children under five years of age was selected for this study. A sample of mothers of the stunted children was selected as key informants. The dependent variable was stunting. The independent variables were maternal knowledge and child dietary intake. The data on stunting were taken from maternal and child health record at Puskesmas. The other data were collected by in-depth interview, focus group discussion, and document review. The data were analyzed by content analysis.

Results: Mothers of stunted children did not worry about their children condition. Stunting was not considered as a serious issue to overcome. Mothers had poor knowledge about stunting, dietary intake, and child health were poor.

Conclusion: Stunting in children under five to some communities in Jepara, Central Java, is not considered as an important issue. Correspondingly mothers of stunted children have poor knowledge about stunting, nutrition, and child growth and development.
\end{abstract}

Keywords: stunting, maternal knowledge, dietary intake, children under five.

\section{Correspondence:}

Ani Margawati. Department of Public Health, Faculty of Medicine, Universitas Diponegoro, Semarang, Central Java. Email: animargawati@gmail.com. Mobile: 081325858445. 